PNNL-11941

UC-2000

\title{
Summary Profiles of Hanford Effluent Release Data
}

\author{
K.M. Tominey \\ M. K. White
}

December 1998

\section{Prepared for}

the U.S. Department of Energy

under Contract DE-AC06-76RLO 1830

Pacific Northwest National Laboratory

Richland, Washington 99352 


\section{DISCLAIMER}

This report was prepared as an account of work sponsored by an agency of the United States Government. Neither the United States Government nor any agency thereof, nor any of their employees, make any warranty, express or implied, or assumes any legal liability or responsibility for the accuracy, completeness, or usefulness of any information, apparatus, product, or process disclosed, or represents that its use would not infringe privately owned rights. Reference herein to any specific commercial product, process, or service by trade name, trademark, manufacturer, or otherwise does not necessarily constitute or imply its endorsement, recommendation, or favoring by the United States Government or any agency thereof. The views and opinions of authors expressed herein do not necessarily state or reflect those of the United States Government or any agency thereof. 


\section{DISCLAIMER}

Portions of this document may be illegible in electronic image products. Images are produced from the best available original document. 


\section{Executive Summary}

Hanford publishes extensive estimates of their offsite releases of various chemical and radiological species annually. In this report we examine using these estimates to develop additional insight into how effectively such releases of hazardous materials are being controlled at Hanford. Historical estimates of airborne and surface water releases of selected contaminants are compared with estimates of the overall Site inventory of those contaminants and with the corresponding release limits and background levels. These comparisons are also examined over a five-year period (1993 to 1997) to determine how these releases have changed during that time.

Most of the waste management and environmental restoration activities under way at Hanford are intended to provide final, permanent disposition of the Site's inventory of hazardous materials, with the ultimate objective of ensuring that risks to the public and the environment are controlled to an acceptable level. An important consideration during the conduct of these activities is protecting the public and the environment while accomplishing the longer-term objectives. The amounts of hazardous materials that are being released to the air or surface water while waste management and environmental activities are being conducted is one important measure of their overall effectiveness.

The comparisons described in this report indicate that measures to control the release of the selected contaminants from the Hanford Site are, and have been, very effective. The amounts of these materials released to surface water and air are very small compared with background and regulatory limits and smaller still considering the inventories under management. Comparisons of annual releases ranged from slightly over background to five orders of magnitude below background levels (e.g., $1 / 10,000^{\text {th }}$ of background levels), and up to 14 orders of magnitude less than estimates of Site inventories. Annual releases for these contaminants ranged from three to ten orders of magnitude less than regulatory limits. In addition, release of the selected contaminants generally decreased over the five-year period examined. 


\section{Acknowledgments}

The authors would like to thank Nancy Wildung (PNNL) for generating the figures that represent the data presented in this report. They would also like to thank Sheila Bennett (PNNL) for her advice and assistance in editing, formatting, and publishing this report. 
D

I

।

।

,

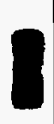

।

I

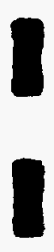

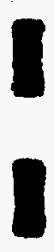

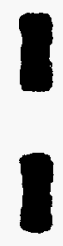

,

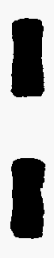




\section{Contents}

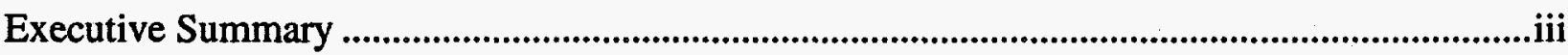

Acknowledgments ......................................................................................................................

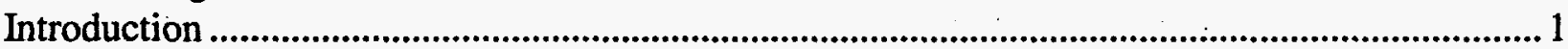

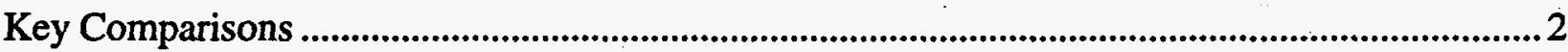

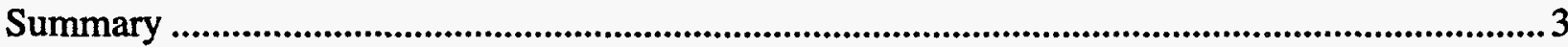

Effluent Release, Environmental Measurements, and Site Inventory Data .....................................5

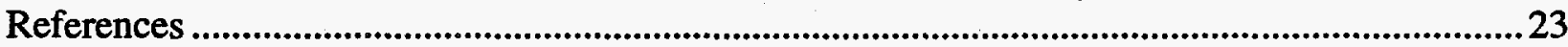

\section{Figures}

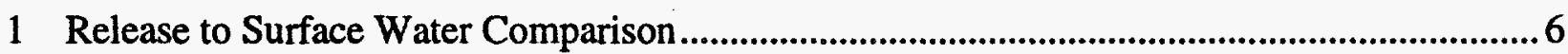

2 Release to Air Comparison .....................................................................................................6

3 Effluent Releases Versus Site Inventory Estimates........................................................................

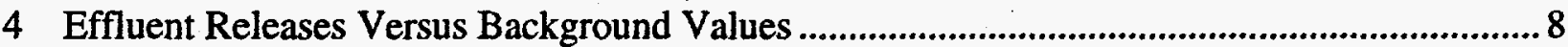

5 Effluent Releases Versus Regulatory Limits.......................................................................

6a Release to Surface Water Versus Site Inventory Estimates ......................................................... 10

6b Release to Air Versus Site Inventory Estimates............................................................................ 10

7a Release to Surface Water Versus Background Values .................................................................11

7b Release to Air Versus Background Values ......................................................................... 11

8a Release to Surface Water Versus Regulatory Limits.................................................................. 12

8b Release to Air Versus Regulatory Limits.............................................................................. 12

\section{Tables}

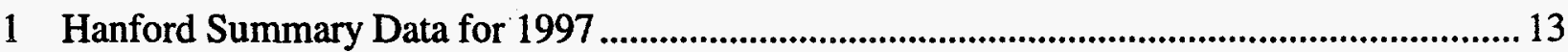

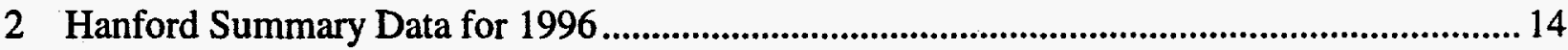

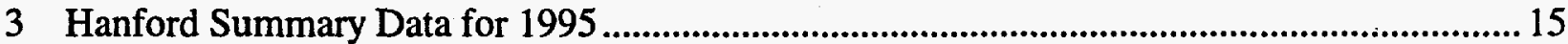

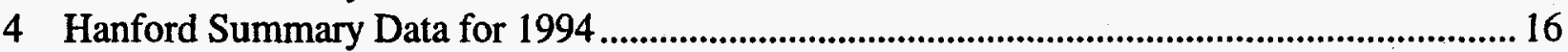

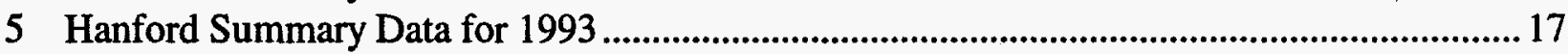

61997 Hanford Effluent Comparison Calculations .......................................................................... 18

71996 Hanford Effluent Comparison Calculations ....................................................................... 19

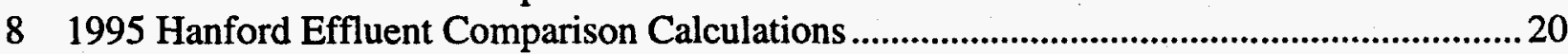

91994 Hanford Effluent Comparison Calculations ............................................................................21

101993 Hanford Effluent Comparison Calculations ......................................................................22 


\section{Introduction}

Extensive information is published annually by each Department of Energy (DOE) Site providing both measurements and estimates of offsite releases of various chemical and radiological species. These releases typically occur as a result of continuing Site mission operations or as a consequence of waste management or environmental operations intended to permanently limit releases from the Site to acceptable levels. The release information published typically addresses whether such releases are within relevant regulatory limits; i.e., whether DOE is "in compliance."

The purpose of this study is to complement annual effluent release information published for Hanford with additional comparisons that put these measured and estimated releases into a broader perspective. Examining effluent releases provides insight into the level of hazard associated with waste management and environmental restoration activities being conducted to permanently reduce the hazards associated with the radionuclide and chemical contaminants onsite. The objective of these longer-term waste management and environmental restoration activities is to dispose of or control onsite contamination in a manner that permanently limits offsite releases to an acceptable level. Current release data indicate how well we are doing in the short term while we pursue these long-term objectives.

This report considers annual release information for Hanford for the years 1993 to 1997. The most recent information published for Hanford is the Hanford Site 1996 Environmental Report (Dirkes and Hanf 1997). Equivalent information for 1993 through 1995 was published in previous annual reports. Effluent release information for 1997, which is considered preliminary until published in the next annual report, was included to allow evaluation of effluent release trends for the most recent five-year period.

The comparisons described here for Hanford are illustrative of the type of higher-level assessments of effluent releases that can be made to put the hazards associated with current operations into perspective. Rather than considering all contaminants of concern individually, as is the case for typical annual effluent release data, aggregate or summary representations of these detailed data are developed to provide a more easily understandable indication of the overall effect of current Site operations. Assessing how such release indicators vary year to year, as different amounts of contamination are actively processed or managed, provides additional assurance that these activities are being conducted in a manner that does not pose an interim hazard as permanent hazard reduction goals are pursued. 


\section{Key Comparisons}

The primary offsite releases of concern at Hanford are airborne releases at the Site boundary and effluent releases to the Columbia River. This summary compares the measured and estimated releases of key contaminants of concern with both the approximate inventory of these contaminants onsite as an indicator of the degree to which they are controlled and with appropriate regulatory limits. In addition, where possible, current releases are compared with the levels of these contaminants that would be experienced even if there were no releases from the Hanford Site (i.e., background levels). Comparing releases with background levels provides additional insight on the relative significance of current releases from Hanford.

Each of these comparisons (effluents-to-inventory, effluents-to-regulatory limits, effluents-to-background) is evaluated for each year from 1993 through 1997. Considering how these effluent comparisons have varied with time allows evaluation of any trends that may be occurring in effluent releases.

The effluent comparisons herein are intended to provide perspective about the relative magnitudes of releases rather than detail their absolute values. These comparisons are primarily concerned with order-of-magnitude (factors of 10,100,1000, etc.) differences between contaminant inventories, releases, and release limits. In addition, for this preliminary evaluation, only radionuclide releases are evaluated because the relevant release data are more readily available. The simplifying assumptions described herein to calculate various contaminant inventories, releases, or release limits are made to facilitate such comparisons rather than to generate precise estimates of the various factors, and the results shown here should be interpreted accordingly. 


\section{Summary}

Figures 1 and 2 illustrate these key comparisons for estimated or calculated air and surface water releases of various contaminants at Hanford from 1993 through 1997. These air and surface-water releases are compared with total inventory estimates, with allowable releases based on regulatory limits, and with typical background levels for each year. Each of these comparisons for each year is represented by a bar showing the variation across a variety or contaminants for that comparison. This convention applies to Figures 3 through 5 as well.

Figure 1 provides summary data for surface water effluent releases to the Columbia River during the most recent five-year period for which data are available. The most recent (1997) comparisons indicate that surface-water releases of contaminants (i.e., releases to the Columbia River) are controlled to 6 to 9 orders of magnitude less than the estimated Site inventory for that year. Similarly, the surface-water releases for the selected contaminants are 4 to 10 orders of magnitude less than regulatory limits and 3 to 5 orders of magnitude less than background levels away from the Hanford Site. The figure also indicates that there has been a gradual decline in these releases over the five-year period, and that the variation in these comparisons across contaminants is decreasing. Estimates of the public health risk associated with these surface water releases indicate that the probability of these effluent releases causing an incremental incidence of cancer ranging from $10^{-9}$ to $10^{-11}$.

Figure 2 shows similar data for airborne releases of contaminants from Hanford facilities. Air releases are controlled to 4 to 12 orders of magnitude less than the Site inventory for these contaminants as of 1997. Releases to the air pathway at Hanford are higher than typical ambient levels for these contaminants ( 1 to 2 orders of magnitude) but are 5 to 8 orders of magnitude lower than relevant regulatory constraints. Figure 2 also indicates that there has been a gradual decline in these airborne releases over the five-year period. Estimates of the public health risk associated with these airborne releases indicate that the probability of their causing an incremental incidence of cancer ranges from $10^{-9}$ to $10^{-12}$.

Figures 1 and 2 appear to indicate that, despite the variety of waste management and environmental restoration activities under way at Hanford during these five years, surface-water and airborne effluent releases have been successfully managed. Both surface water and airborne releases are many orders of magnitude lower than corresponding regulatory limits and have generally been declining relative to such limits.

The data used to develop the comparisons illustrated in Figures 1 and 2 are discussed in the next section. In addition, Figures 3-8 present the data illustrated in Figures 1 and 2 in more detail and in a variety of formats. Figures 3 through 5 show the annual representation of the each of the three key comparisons (release to inventory, release to background concentration, release to regulatory limit) individually to facilitate assessment of how these comparisons have varied between 1993 through 1997. Figures 1 through 5 illustrate the variation in these comparisons across a variety of contaminants. Figures 6 through 8 provide the contaminant-specific information for each of the five years. 
The key assumptions for these comparisons are described in more detail below. However, a few general comments are pertinent for interpreting the results. The "inventory" estimates shown for the various contaminants typically represent a summation of the estimated inventories for the major Site sources of each of seven selected contaminants rather than a comprehensive estimate of total Site inventory for these contaminants. Therefore, the inventory data on the figure should be interpreted as meaning that there is at least the indicated inventory onsite. Since the significant information is that releases are many, many orders of magnitude lower than what is present, this approximation provides a conservative indication of the degree of management or control of the contaminant being achieved by current operations or practices.

Similarly, the "regulatory limit" information shown for each contaminant represents the most restrictive of the potentially relevant regulatory constraints appropriate for airborne or surface-water releases. Again, this provides a conservative indication of how currently estimated or calculated releases compare with potentially allowable releases. 


\section{Effluent Release, Environmental Measurements, and Site Inventory Data}

The source data used to develop the comparisons shown in Figures 1 through 8 can be found in Tables 1 through 5; the calculated results shown in the figures are found in Tables 6 through 10. The contaminants listed on these tables were selected from among those for which effluent release data were reported in the Hanford Site annual environmental reports for the most recent five-year period (1993 through 1997). They were selected as representative of the contaminants of major interest. The effluent release values reported on these are from those five annual reports. Total releases were reported in the documents and corresponding concentrations were calculated as described on the tables. The limiting concentration for releases to surface water or to the air pathway shown on the table are based on Ambient Surface Water Quality (ASWQ) standards or Air Quality Standards and/or Derived Concentration Guideline (DCGs) for water or air, respectively. Where both values are given, the more restrictive was selected. While these are not regulatory limits in the strictest sense (other constraints may apply for specific contaminants or releases), they provide a reasonable context for assessing the relative magnitude of effluent releases.

The release, inventory, regulatory limit, and background concentration data shown in Tables 1-5 were developed from both Hanford-specific reports and DOE complex-wide reports. The sources of these data are listed in the tables.

Also shown in Tables 1-5 are "unit risk factors" developed for use in the Hanford Risk Assessment-Environmental Impact Statement (HRA-EIS). These provide a way to approximate the public health hazard associated with the various offsite release estimates. These factors relate the incremental cancer risk for the various contaminants for each pathway (surface water or airborne release) to the corresponding release concentration. Although using these factors will not suffice for estimating the risk associated with any specific release scenario (a risk assessment is required), they do provide a reasonable basis for approximating typical risk levels.

The data in Tables 6-10 were used to develop the comparisons shown in Figures 1 through 8. Comparison of total annual releases to Site inventory for each pathway (surface water or airborne) were developed by calculating the fraction of the release for each contaminants and its estimated inventory. Similarly, each estimated release was compared with its corresponding appropriate regulatory concentration limit or background concentration by calculating the appropriate fraction. 

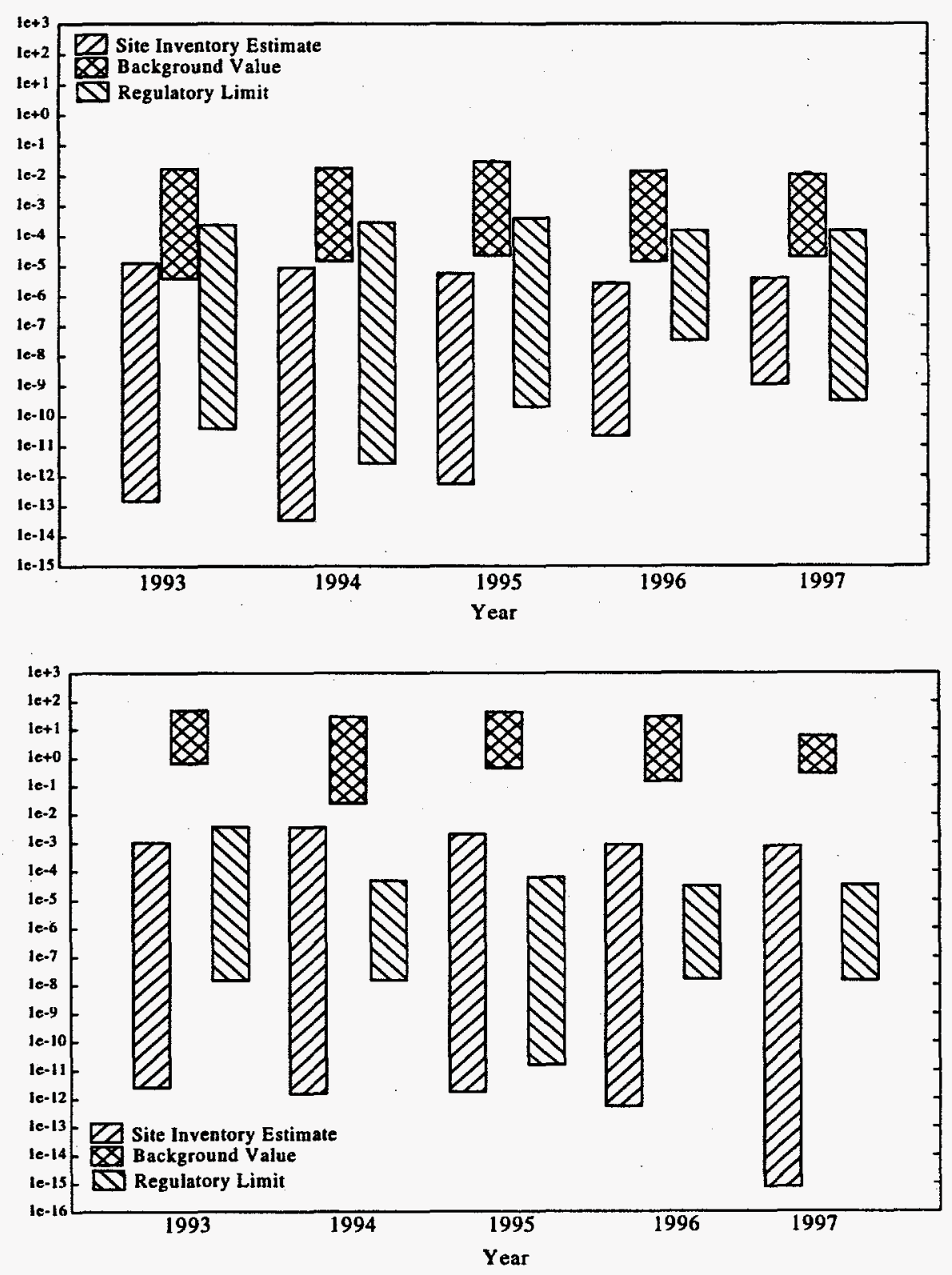

Figure 1. Release to Surface Water Comparison Figure 2. Release to Air Comparison 


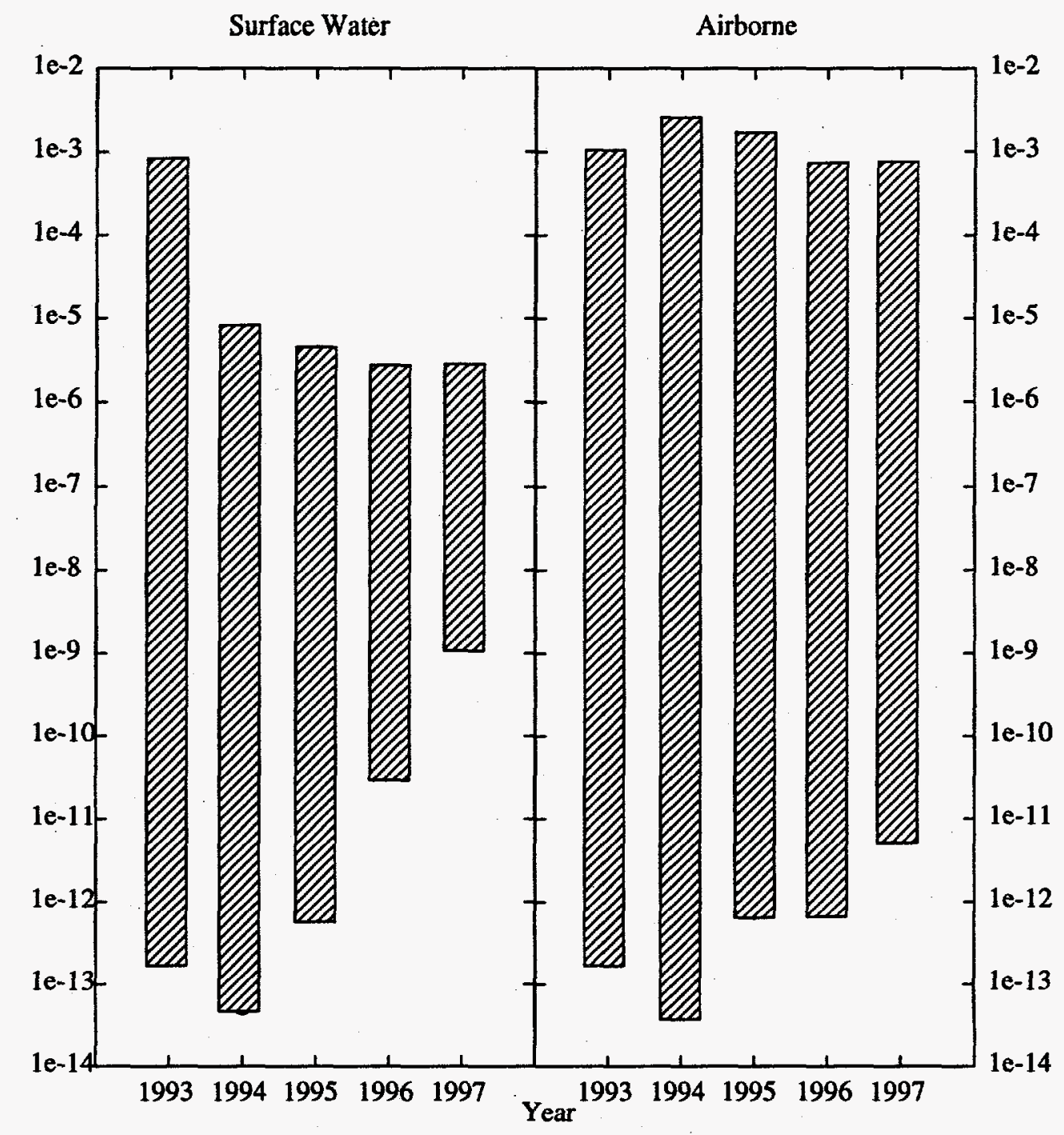

Figure 3. Effluent Releases Versus Site Inventory Estimates 


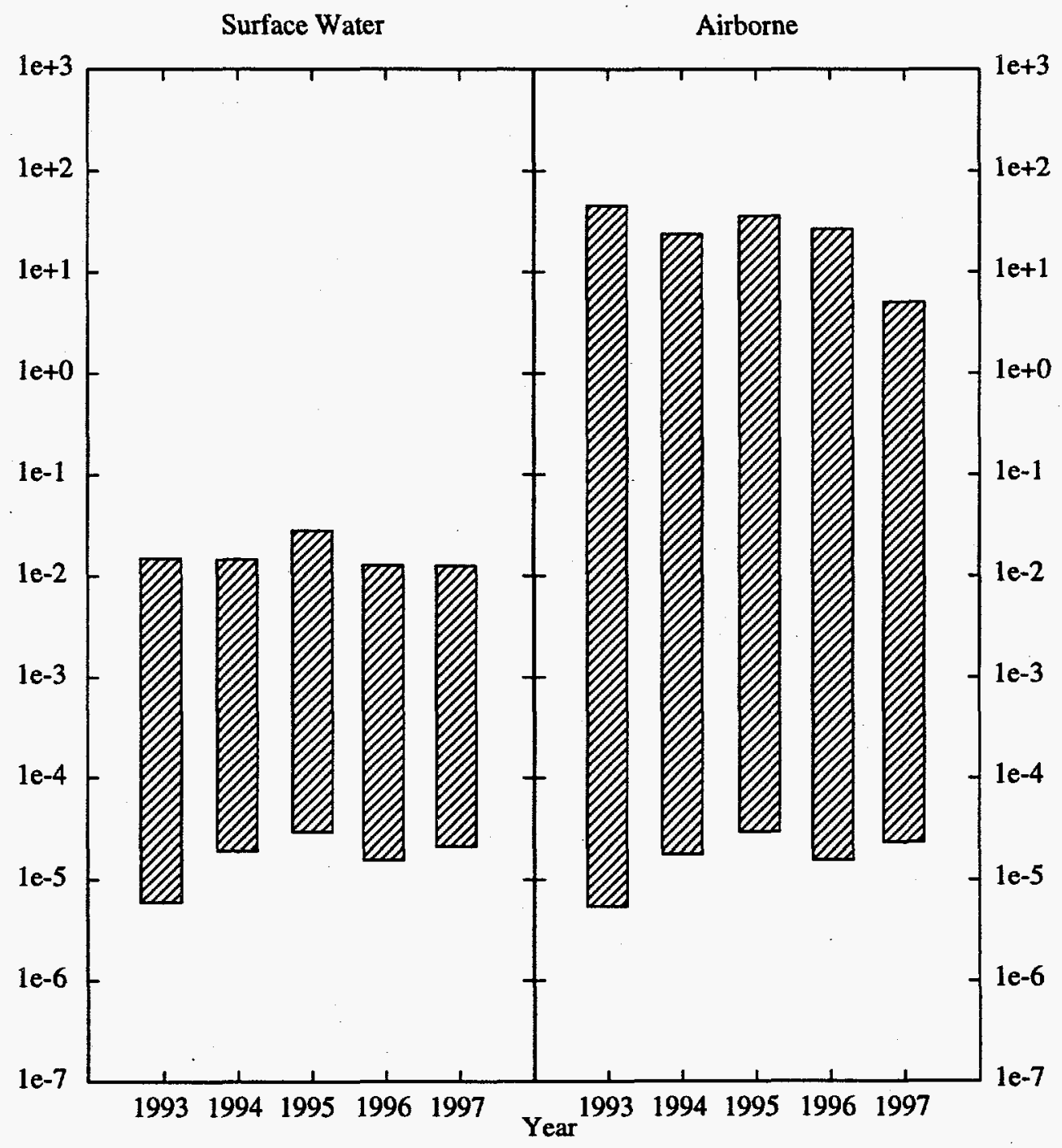

Figure 4. Effluent Releases Versus Background Values 


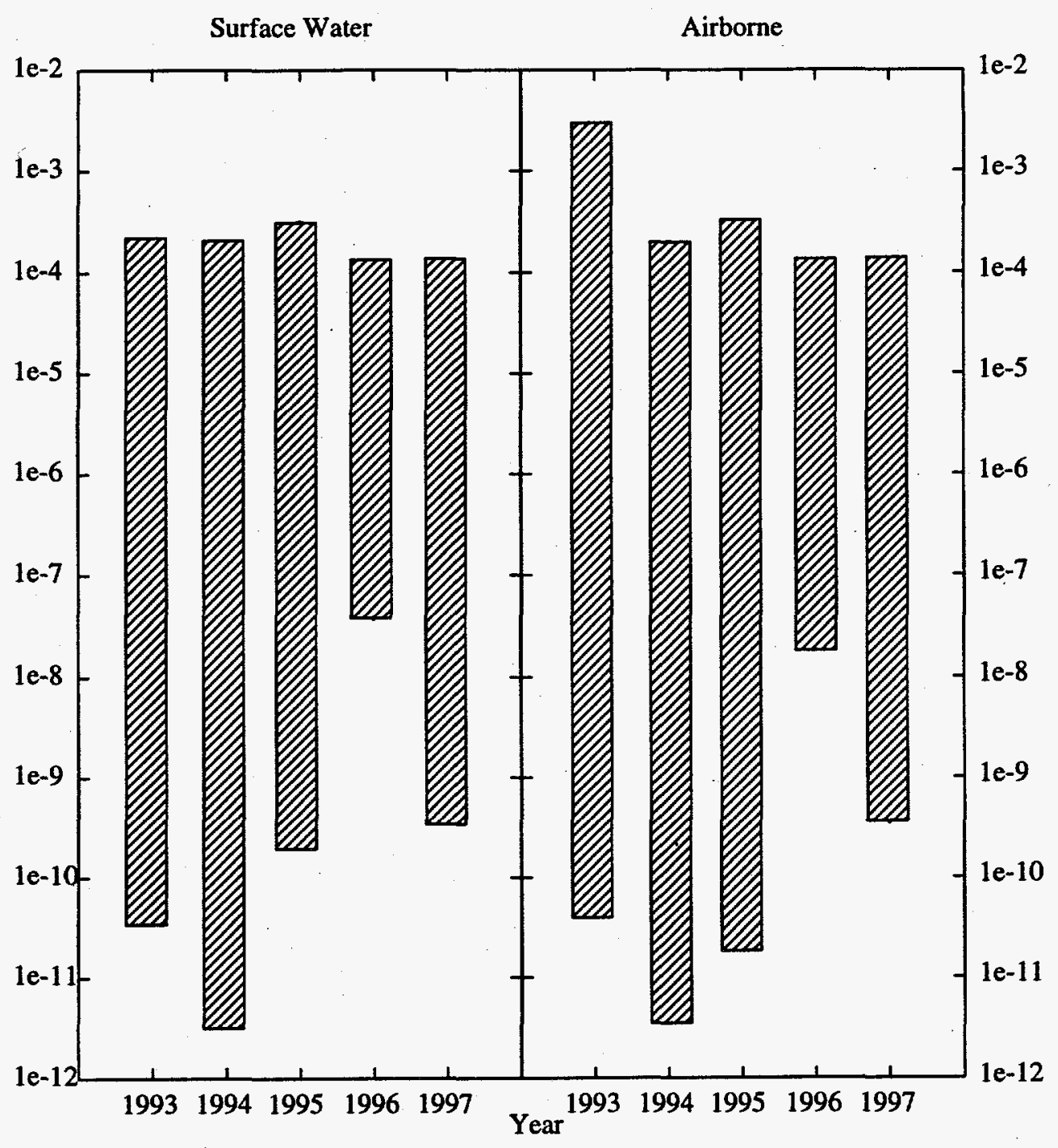

Figure 5. Effluent Releases Versus Regulatory Limits 

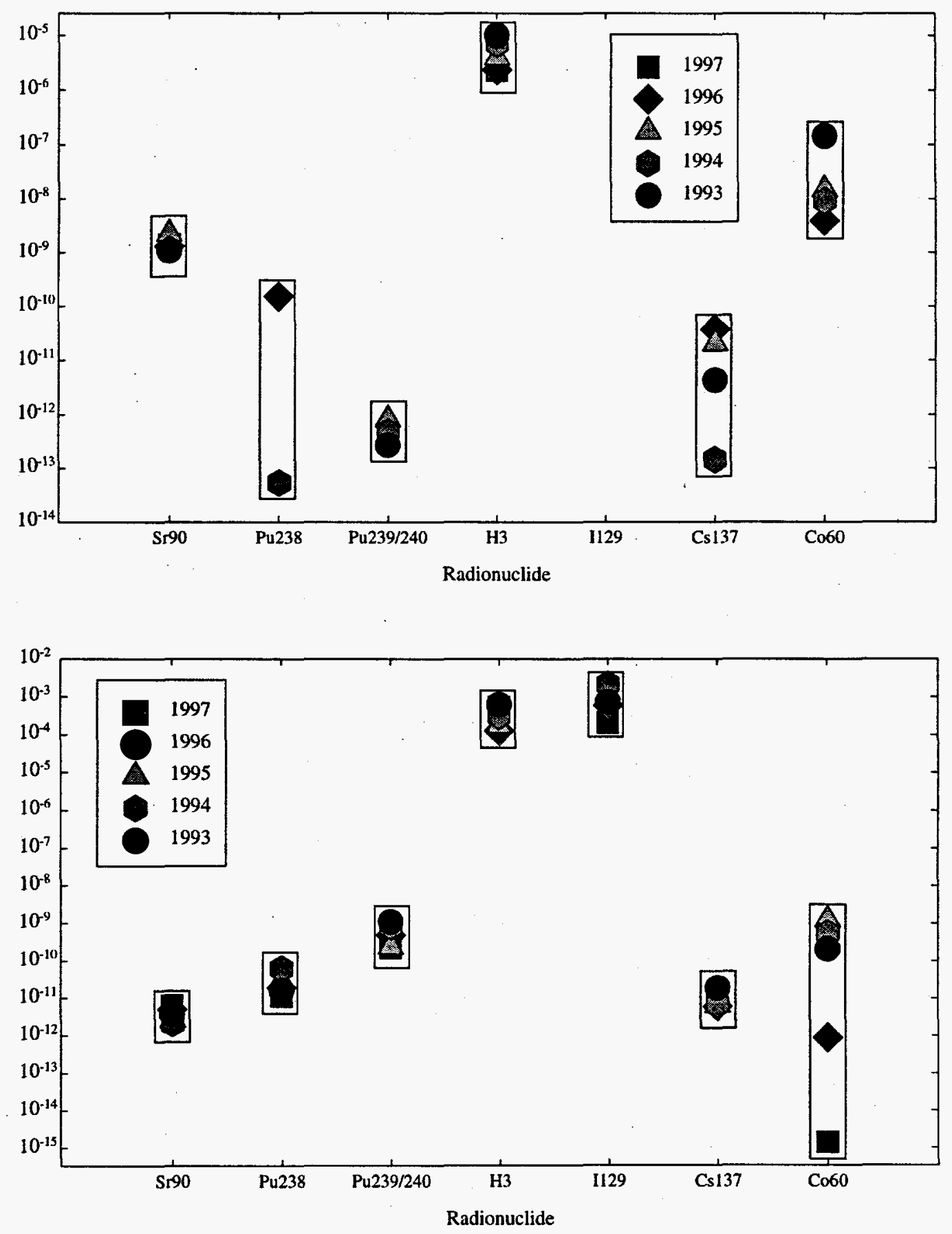

Figure 6a. Release to Surface Water Versus Site Inventory Estimates Figure 6b. Release to Air Versus Site Inventory Estimates 

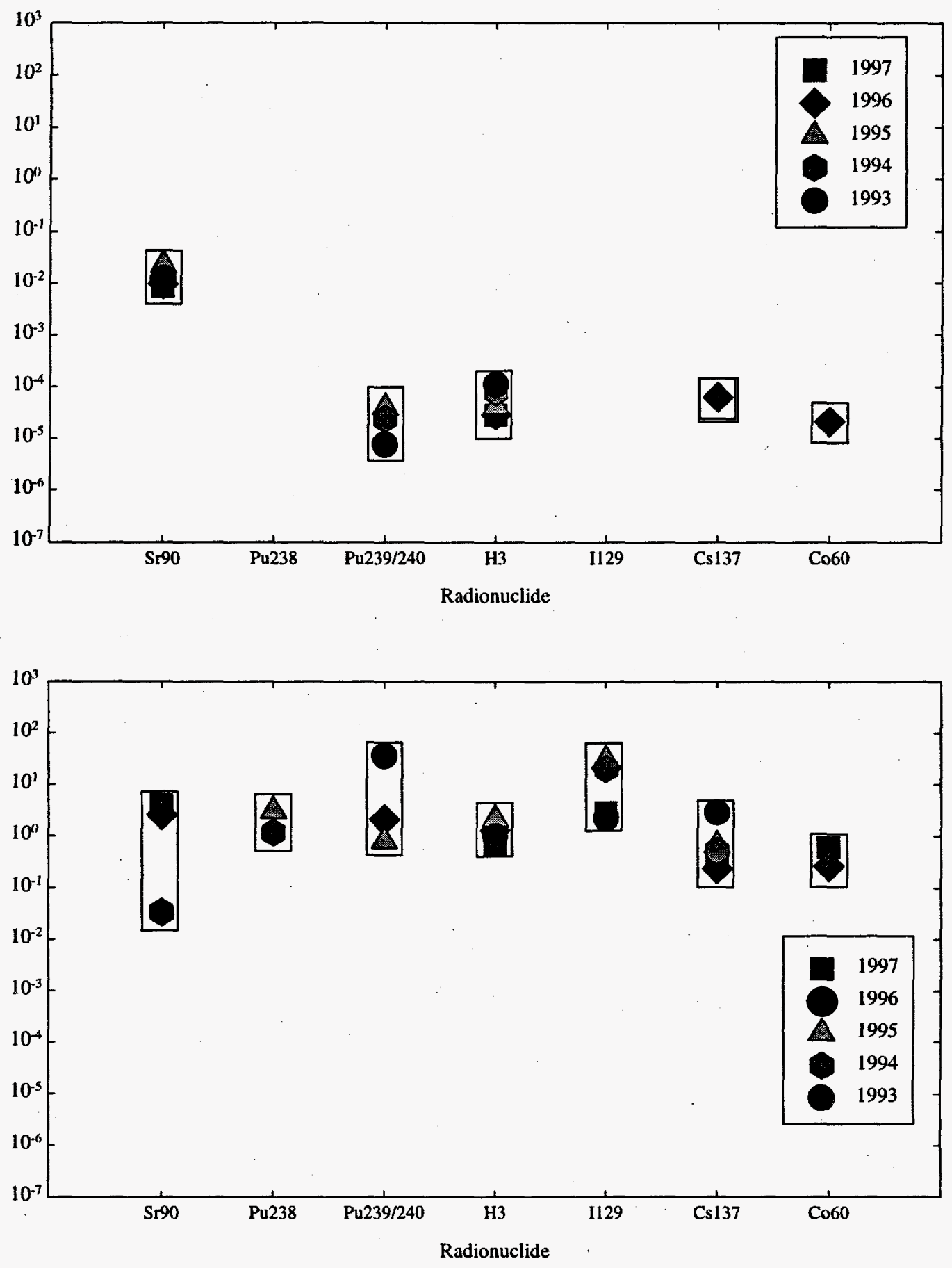

Figure 7a. Release to Surface Water Versus Background Values Figure 7b. Release to Air Versus Background Values 

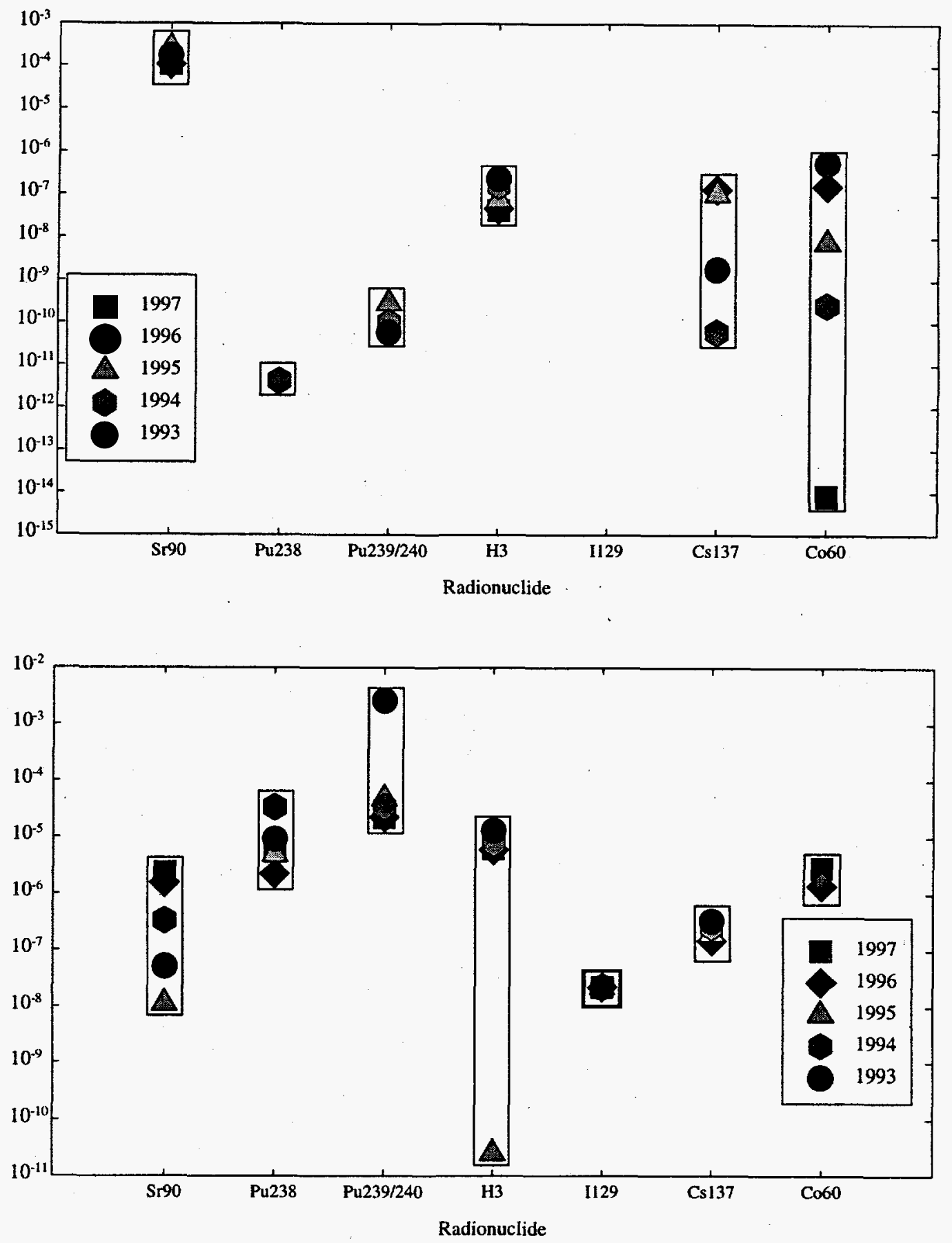

Figure 8a. Release to Surface Water Versus Regulatory Limits Figure 8b. Release to Air Versus Regulatory Limits 


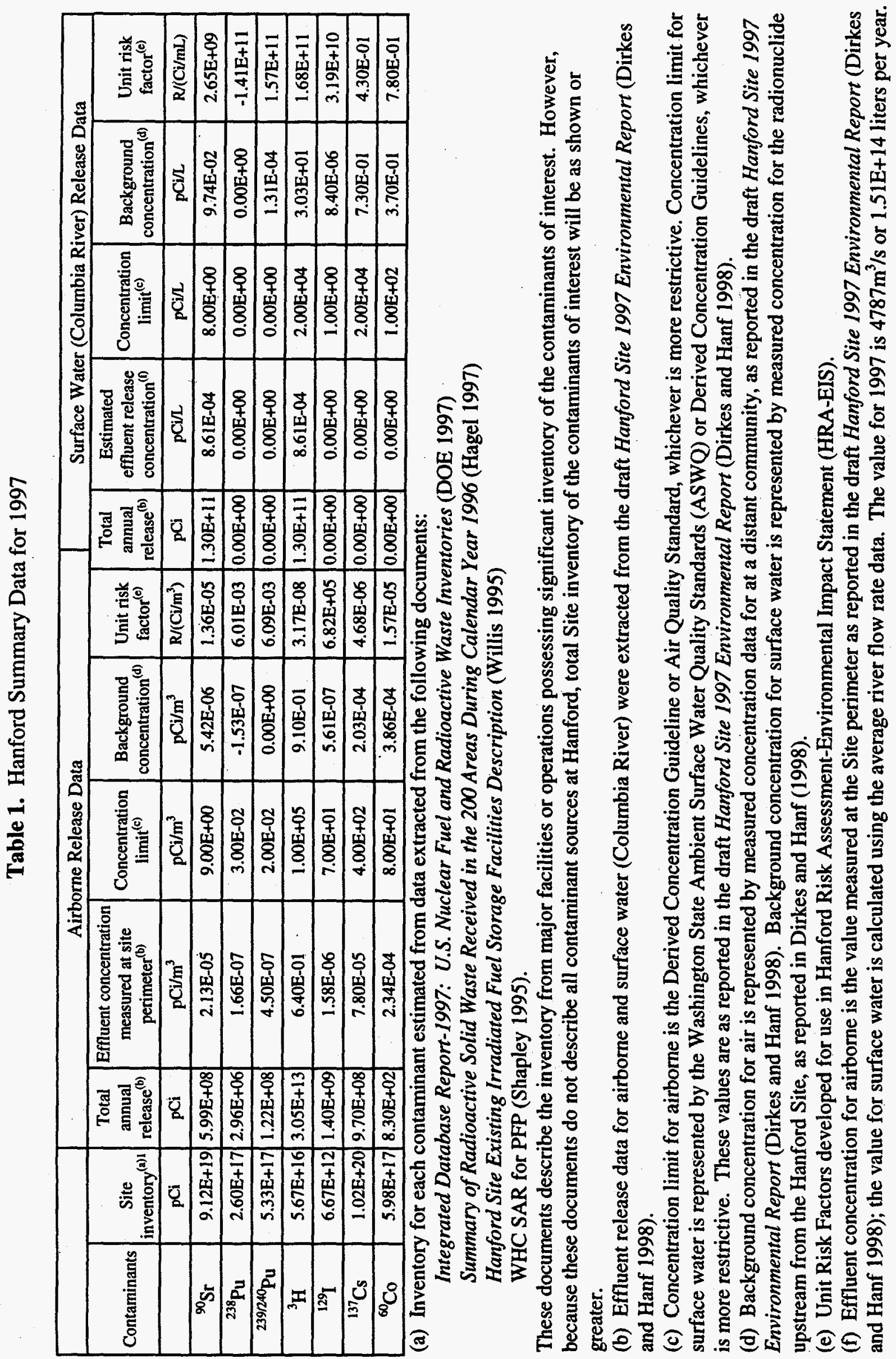




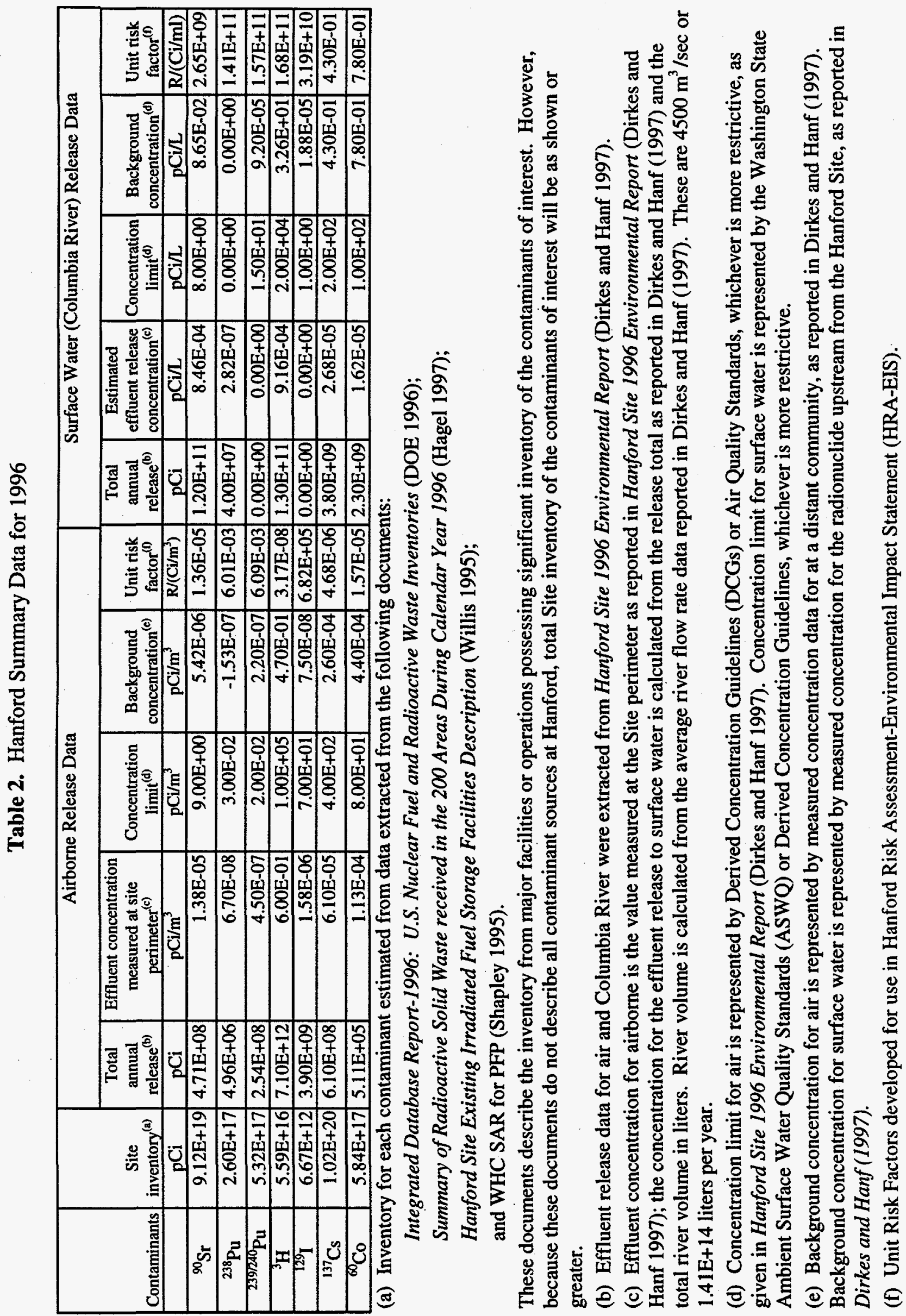




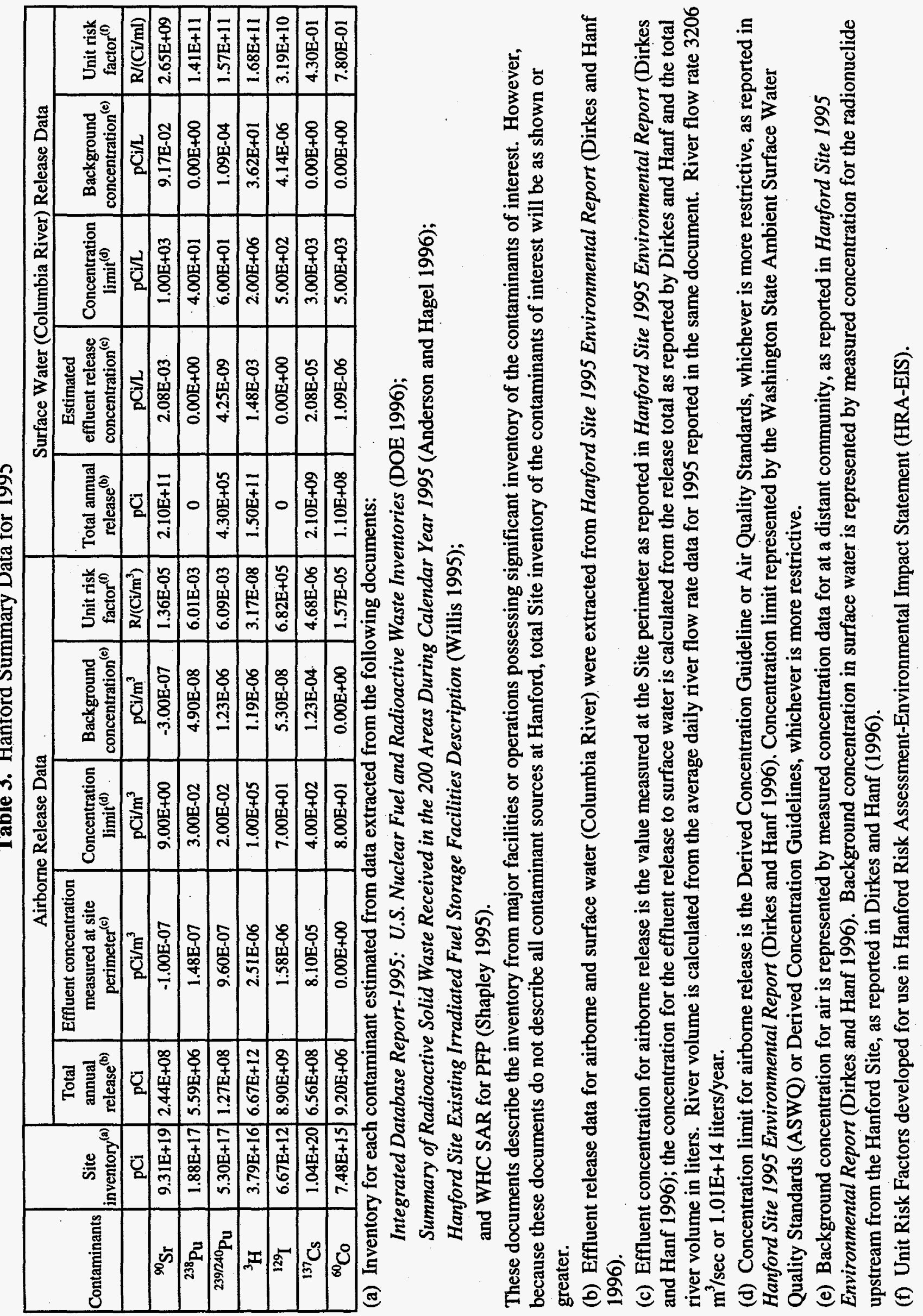




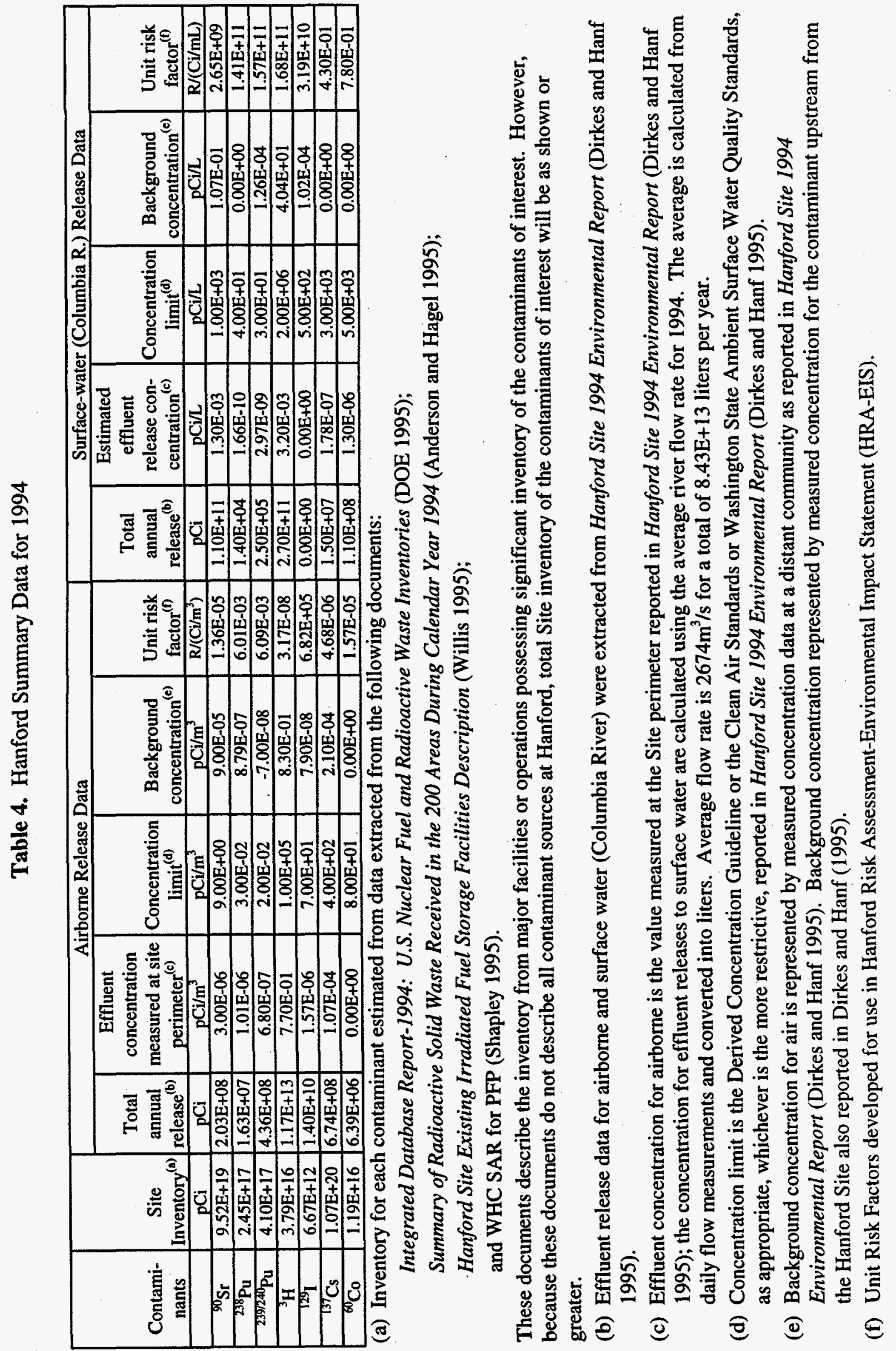




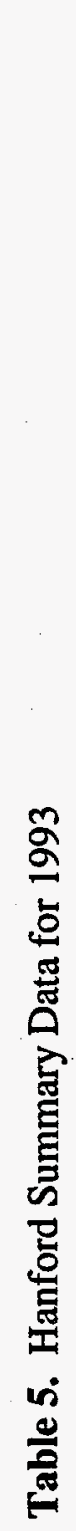

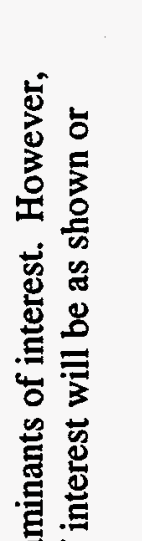

홀

苋

ב.

宇

을

밍

要

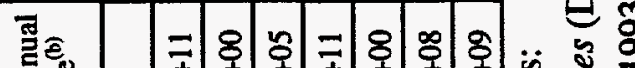

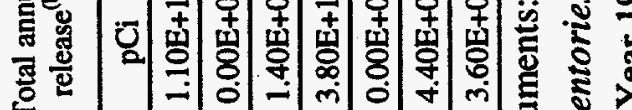

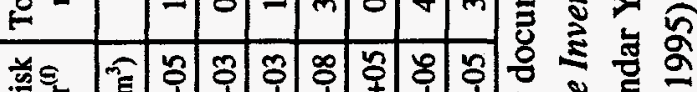

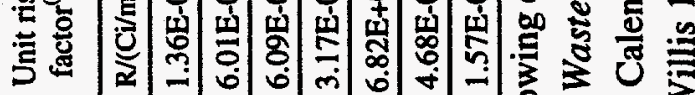

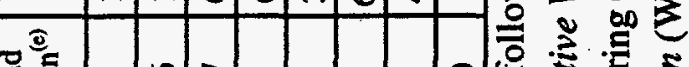

节言 \%

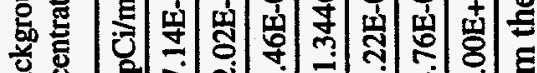

苋苋

릉 융

焉

.

롱 궁

总总

$\cdot \frac{\infty}{\infty} . \Xi$

哭.

岁

:

동

氙正
킁

क्ष.

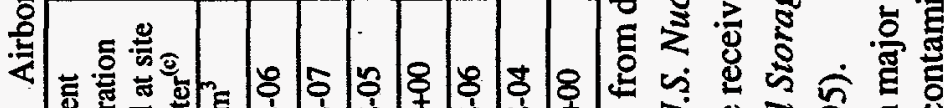

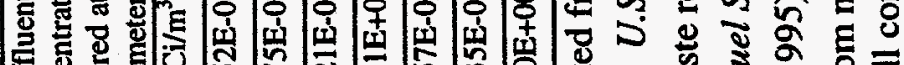

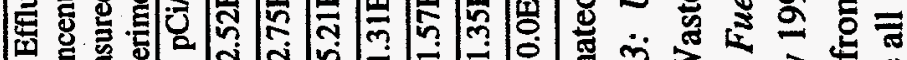
ठั.

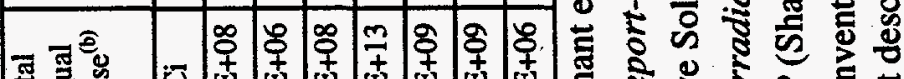

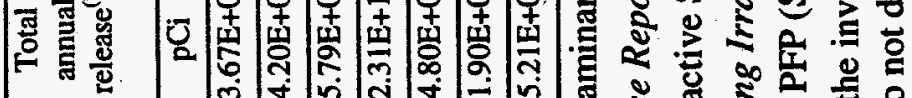
蛋

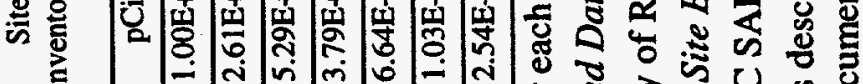

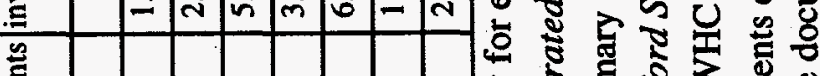

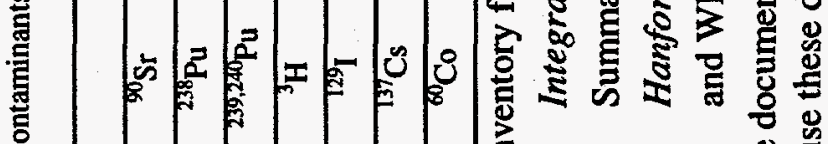

嵌

충

ธ。 乌్

.

己ृ

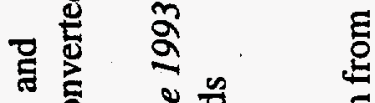

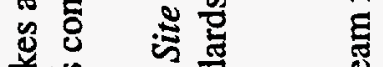

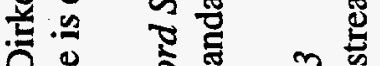

อัँ

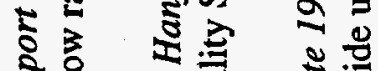

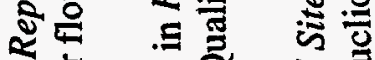

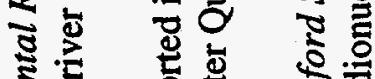

ฐ क्ष

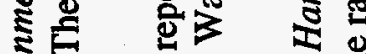

क्ष

氧

जे है है

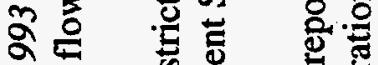

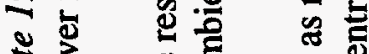

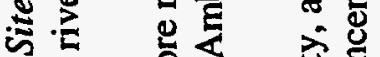

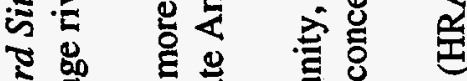

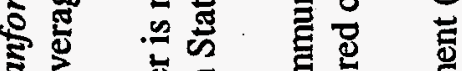

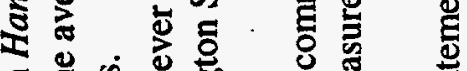

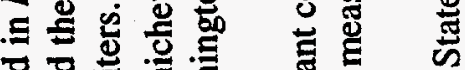

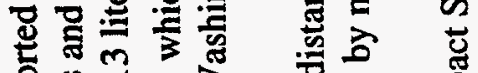

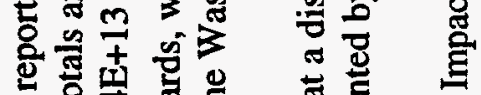

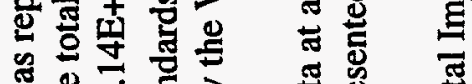

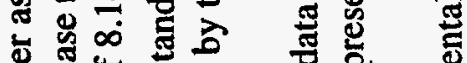

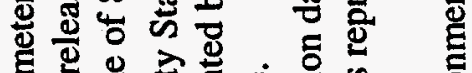

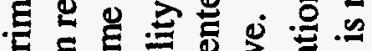

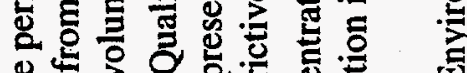

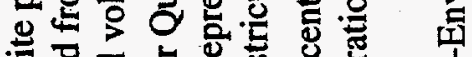

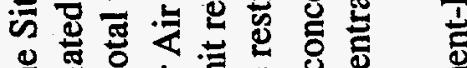

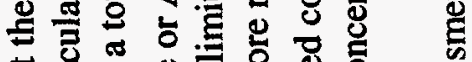

흔

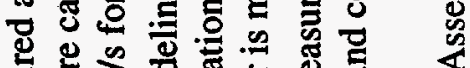

สี

苛

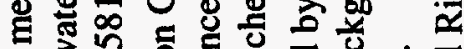

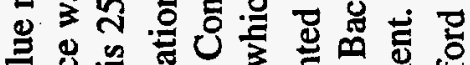

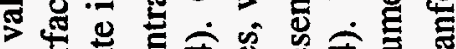

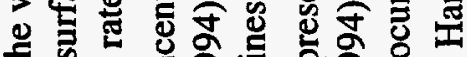

क के .

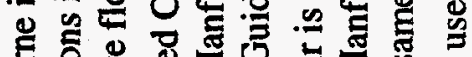

등을

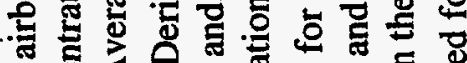

एर

눈

ธิ。

-

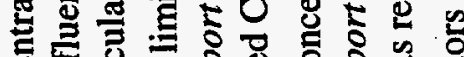

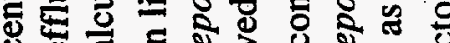

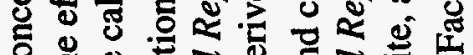
ए

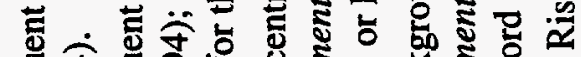

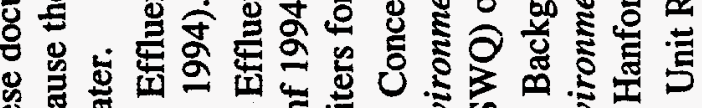

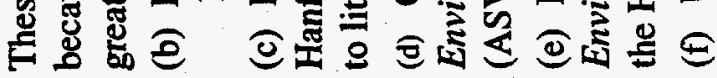




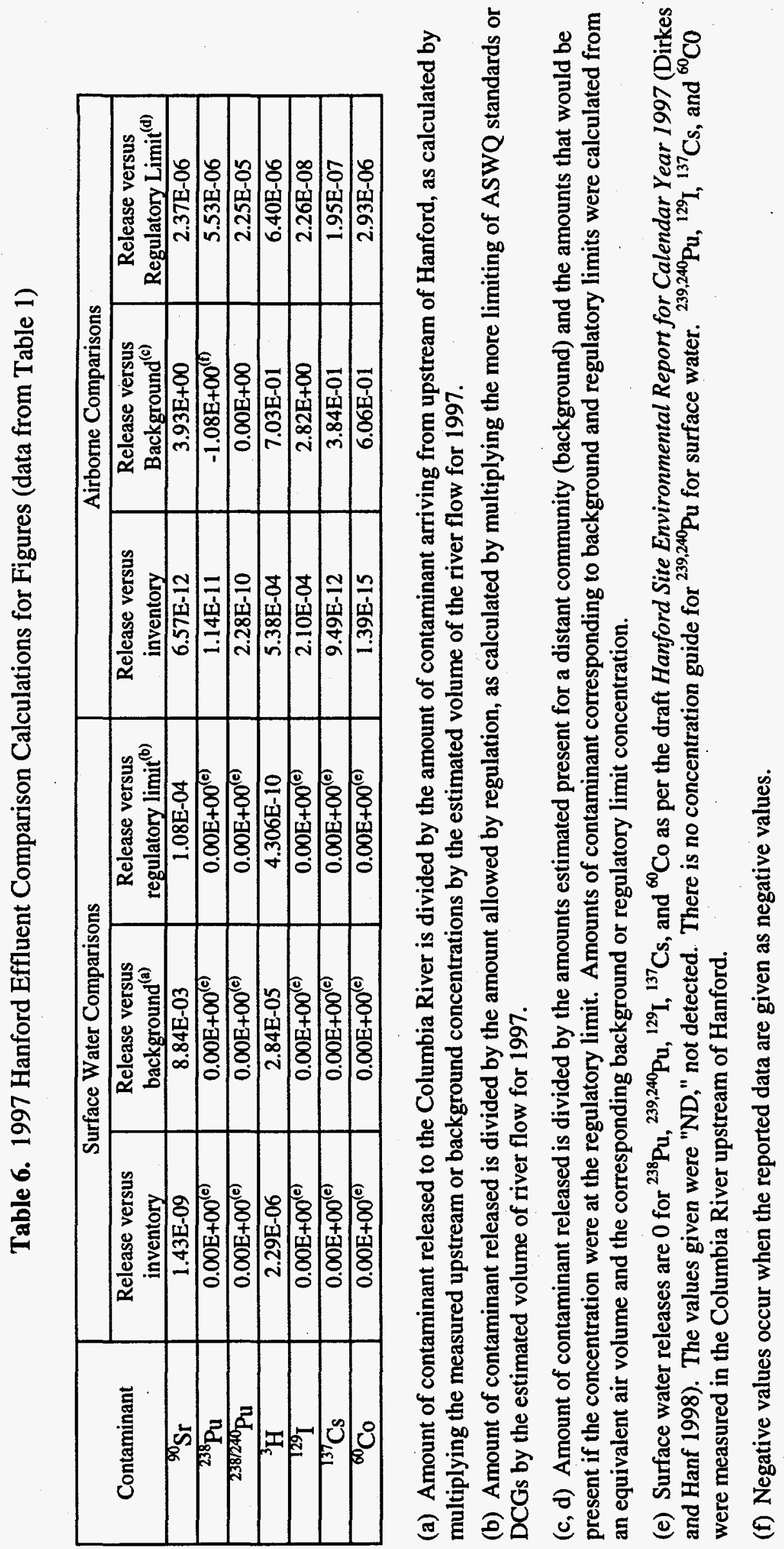




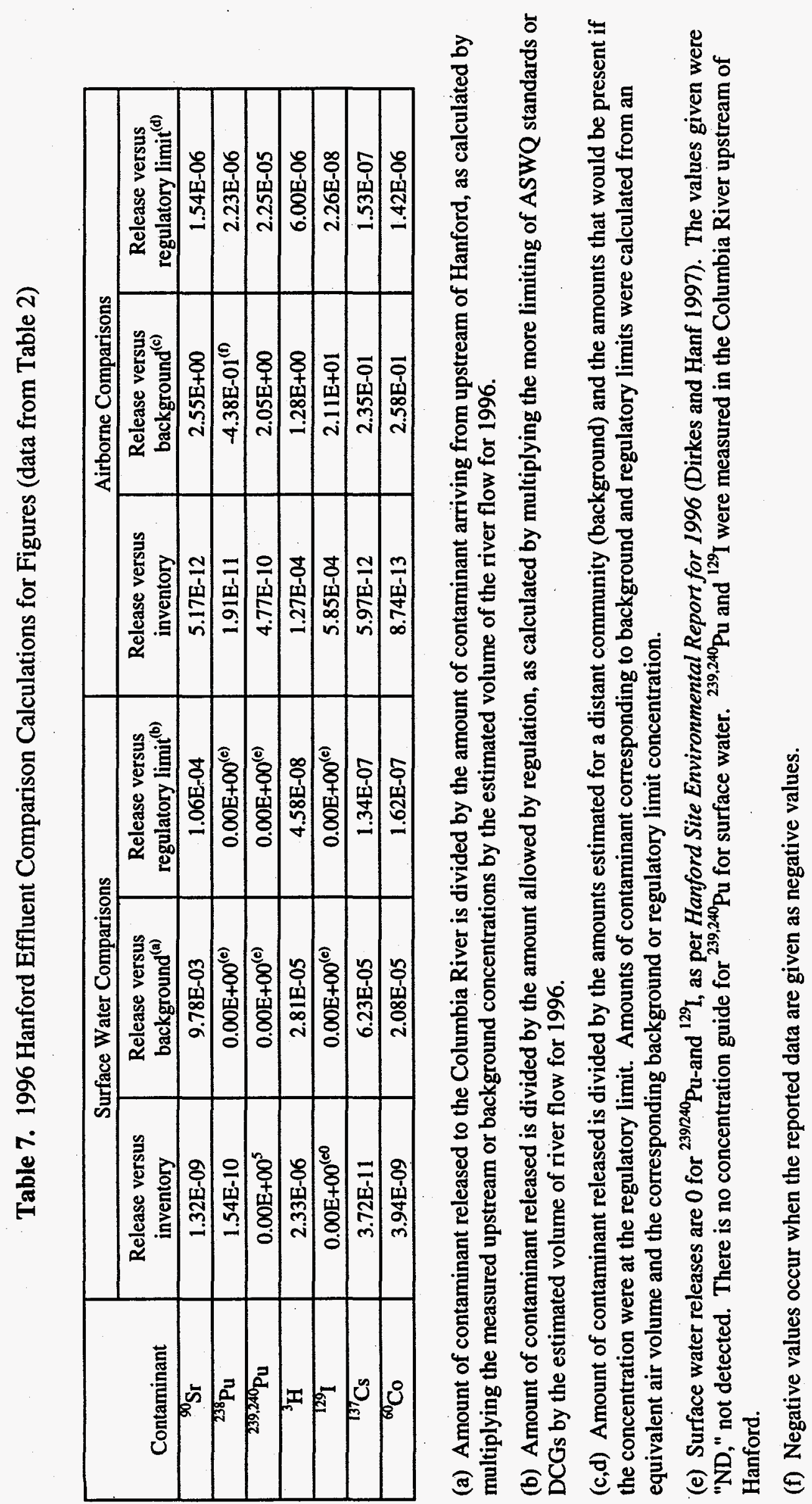




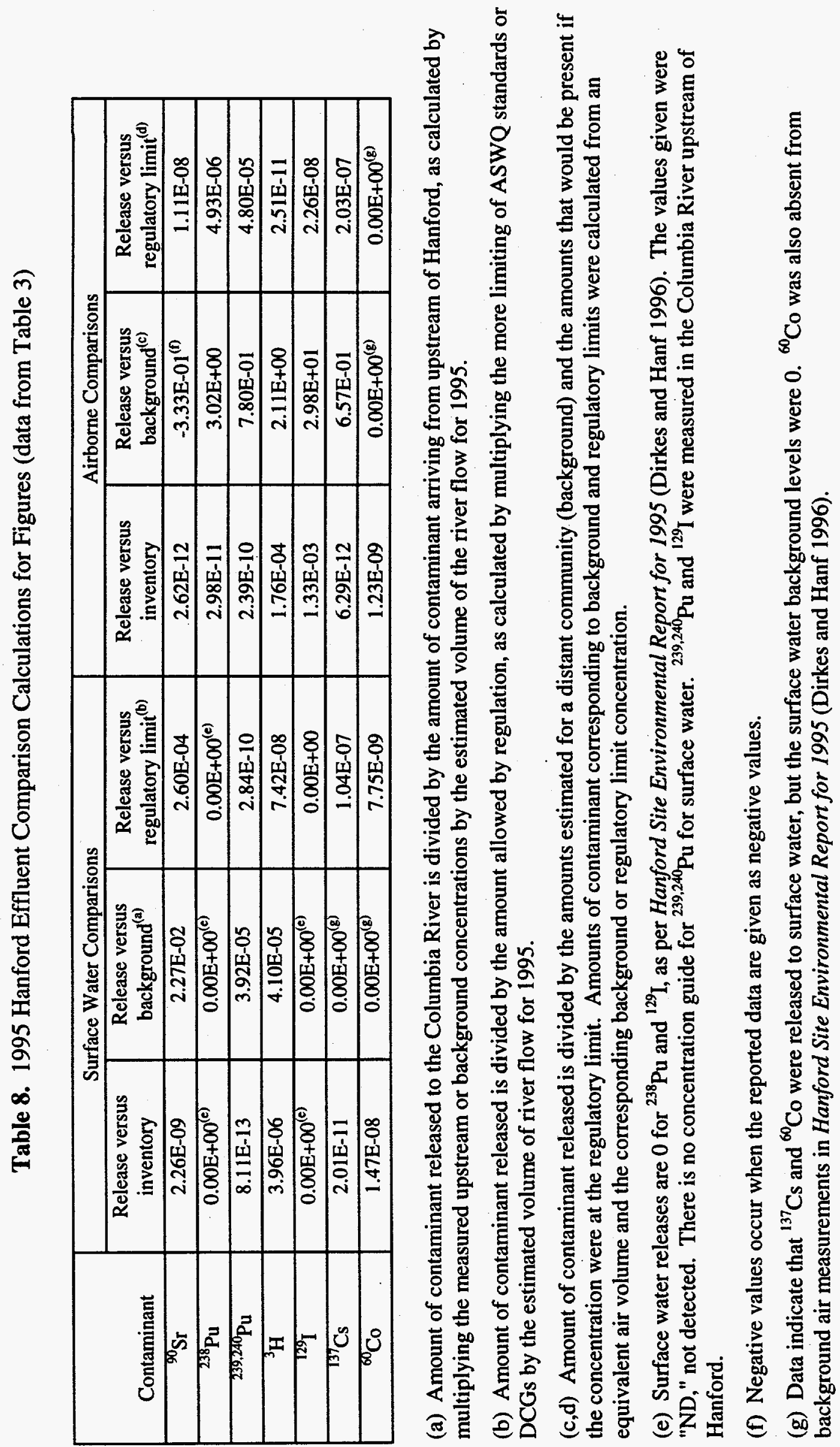




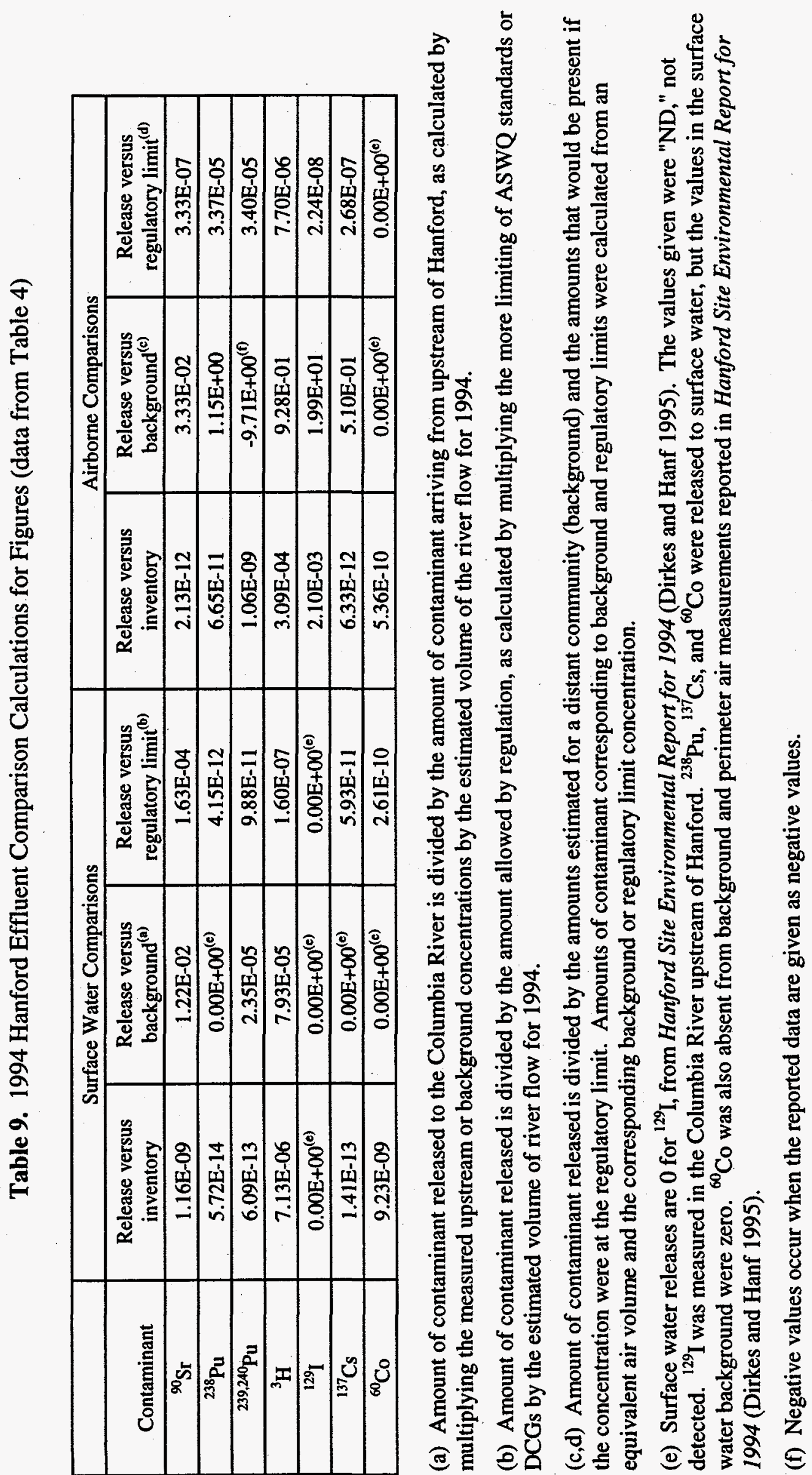




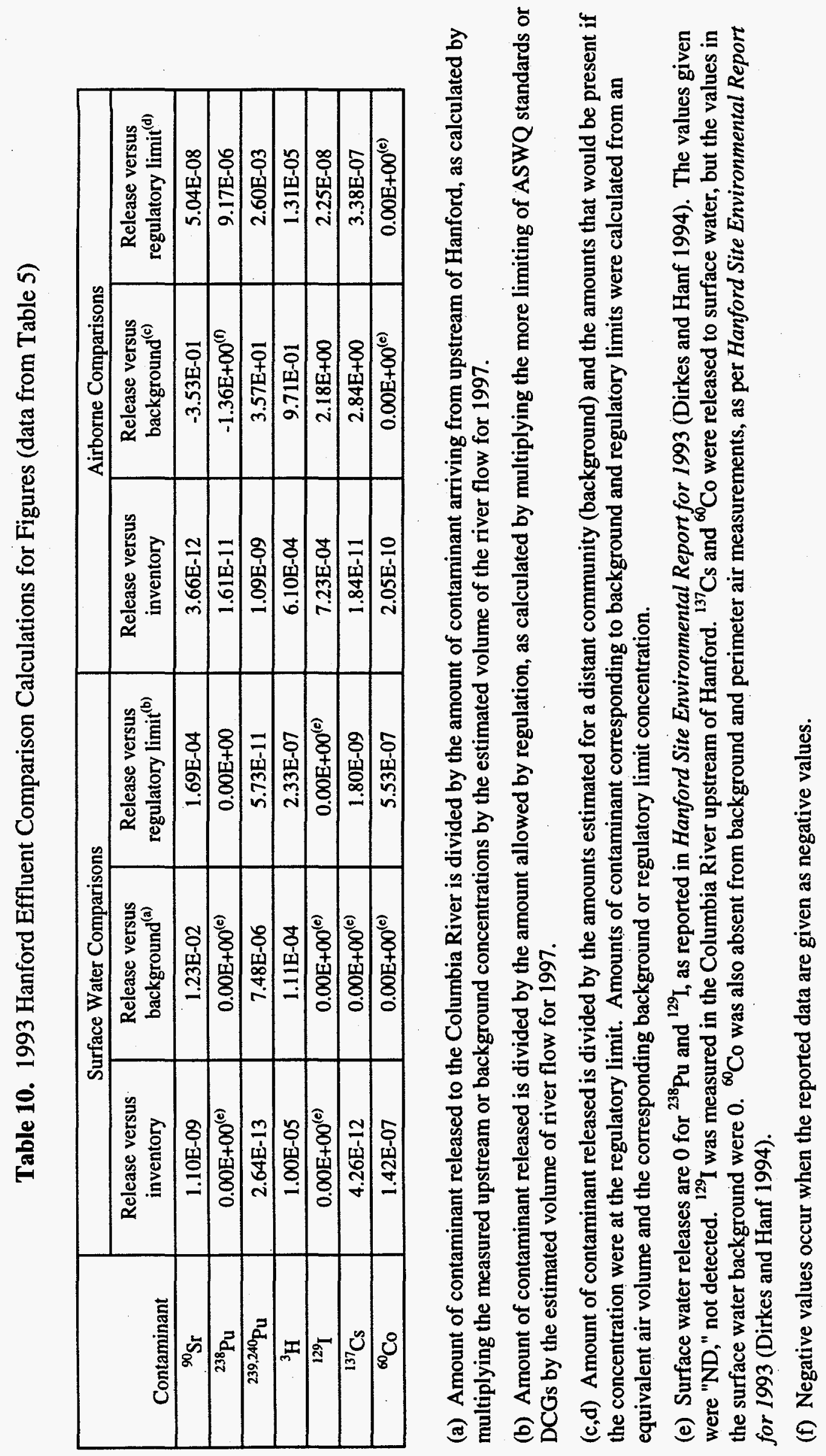




\section{References}

Anderson JD and DL Hagel. 1996. Summary of Radioactive Solid Waste Received in the 200 Areas During Calendar Year 1995. WHC-EP-0125-8, Westinghouse Hanford Company, Richland, Washington.

Anderson JD and DL Hagel. 1995. Summary of Radioactive Solid Waste Received in the 200 Areas During Calendar Year 1994. WHC-EP-0125-7, Westinghouse Hanford Company, Richland, Washington.

Anderson JD and DL Hagel. 1994. Summary of Radioactive Solid Waste Received in the 200 Areas During Calendar Year 1993. WHC-EP-0125-6, Westinghouse Hanford Company, Richland, Washington.

Dirkes RL and RW Hanf. 1998. Hanford Site Environmental Report for Calendar Year 1997 (draft). PNNL-11795, Pacific Northwest National Laboratory, Richland Washington

Dirkes RL and RW Hanf. 1997. Hanford Site Environmental Report for Calendar Year 1996. PNNL-11472, Pacific Northwest National Laboratory, Richland Washington

Dirkes RL and RW Hanf. 1996. Hanford Site Environmental Report for Calendar Year 1995. PNNL-11139, Pacific Northwest National Laboratory, Richland Washington

Dirkes RL and RW Hanf. 1995. Hanford Site Environmental Report for Calendar Year 1994. PNNL-10574, Pacific Northwest National Laboratory, Richland Washington

Dirkes RL and RW Hanf. 1994. Hanford Site Environmental Report for Calendar Year 1993. PNNL-9823, Pacific Northwest National Laboratory, Richland Washington

Hagel DL. 1997. Summary of Radioactive Solid Waste Received in the 200 Areas During Calendar Year 1996. HNF-EP-0125-9, Rust Federal Services of Hanford, Inc, Richland, Washington.

Shapley JE. 1995. Plutonium Finishing Plant Final Safety Analysis Report. WHC-SD-CPSAR-021 Rev 0, Westinghouse Hanford Company, Richland, Washington.

United States Department of Energy. 1997. Integrated Database Report-1996: U.S. Nuclear Fuel and Radioactive Waste Inventories, Projections, and Characteristics. DOE/RW-006 Rev 13, Oak Ridge National Laboratory, Oak Ridge, Tennessee. 
United States Department of Energy. 1996. Integrated Database Report-1995: U.S. Nuclear Fuel and Radioactive Waste Inventories, Projections, and Characteristics. DOE/RW-006 Rev 11, Oak Ridge National Laboratory, Oak Ridge, Tennessee.

United States Department of Energy. 1995. Integrated Database Report-1994: U.S. Nuclear Fuel and Radioactive Waste Inventories, Projections, and Characteristics. DOE/RW-006 Rev 10, Oak Ridge National Laboratory, Oak Ridge, Tennessee.

United States Department of Energy. 1994. Integrated Database Report-1993: U.S. Nuclear Fuel and Radioactive Waste Inventories, Projections, and Characteristics. DOE/RW-006 Rev 9, Oak Ridge National Laboratory, Oak Ridge, Tennessee.

Willis WL. 1995. Hanford Site Existing Irradiated Fuel Storage Facilities Description. WHCSD-SNF-TI-002 Rev 0, Westinghouse Hanford Company, Richland, Washington. 


\section{Distribution}

No. of

Copies

2 Office of Scientific and Technical Information

10 Mark Gilbertson

Forrestal Bldg, 3E066

1000 Independence Ave SW

Washington, DC 20585

10 Al Young

Chicago Operations Office

9800 S. Cass Ave. Bldg 201

Argonne, Ill 60439

Mark Bolliger

Chicago Operations Office

9800 S. Cass Ave. Bldg 201

Argonne, Ill 60439

Loren Habegger, Ph.D.

9700 South Cass Ave. Bldg 900

Argonne, IL 60439-4832

Margaret Macdonnel

9700 South Cass Ave. Bldg 900

Argonne, IL 60439-4832
No. of

Copies

3 DOE Richland Operations Office

R.A. Pressentin

K8-50

J.D. Kautsky

A5-58

J.L. Daily

A5-58

41 Pacific Northwest National Laboratory

J.F. Adams

K8-15

W.B. Andrews (10)

K7-10

S.Q. Bennett

K 7-90

R.L. Dirkes

K6-75

W.T. Farris

K3-54

T.T. Jarvis

J.C. Lavender

K6-80

T.M. Poston

K8-03

M.J. Quadrel

K6-75

R.D. Stenner

K9-18

K3-54

K.M. Tominey (10)

K7-97

M.K. White (5)

K7-94

N.J. Wildung

K7-94

T.W. Wood

K7-94

Information Release (5)

K1-06 